\title{
Model Pembelajaran Olahraga Renang Anak Usia Dini: Literature Review
}

\author{
Asrori Yudha Prawira, Eko Prabowo, Fajar Febrianto \\ Program Studi Pendidikan Kepelatihan Olahraga, Universitas Bhayangkara Jakarta Raya \\ asrori.yudhaprawira@dsn.ubharajaya.ac.id
}

\begin{abstract}
The purpose of this research is to acquire new knowledge and discoveries. The second is to prove or test the correctness of existing knowledge and the third to find out the development of swimming sports models in early childhood. This research is library research. The data in this study are secondary data. The data collection method used in this research is the documentation method. The method of analysis used is article content analysis. Research articles that match the criteria are then collected and a journal summary is made including the name of the researcher, the year of publication of the journal, study design, research objectives, samples, instruments (measuring instruments) and a summary of the results or findings. There are 10 literature that discusses the swimming learning model in early childhood, all of these journals are national journals that do a google scholar diportal search by typing the keyword "swimming learning model" which is then analyzed using critical appraisal analysis to analyze from the core of the journal, the results of the study. so that you know the similarities and differences of these journals. Of the 10 journals, there were 5 journals where swimming games were not examined directly, some discussed gross motor skills, game modification and abilities. Several important things were obtained from several journals, including the identification of early childhood swimming sports learning methods by describing the effective methods of several related studies in order so that they can be used as a reference for learning sports early childhood swimming sports. Second, the renang sports learning model in early childhood can increase enthusiasm and prevent boredom in early childhood. Third, it has a positive effect on gross motor skills and cognitive abilities in early childhood and the learning process is more enjoyable and participatory.
\end{abstract}

Keywords: Literature Research, Swimming Learning Models, Early Childhood

\begin{abstract}
ABSTRAK
Tujuan penelitian ini adalah memperoleh pengetahuan dan penemuan baru. Kedua sebagai pembuktian atau pengujian tentang kebenaran dari pengetahuan yang sudah ada dan yang ketiga untuk mengetahui pengembangan model Olahraga renang pada anak usia dini. Penelitian ini merupakan penelitan kepustakaan (library research). Data dalam penelitian ini adalah data sekunder. Metode pengumpulan data yang digunakan dalam penelitian ini adalah metode dokumentasi. Metode analisis yang digunakan menggunakan analisis isi artikel. Artikel penelitian yang sesuai dengan kriteria kemudian dikumpulkan dan dibuat ringkasan jurnal meliputi nama peneliti, tahun terbit jurnal, rancangan studi, tujuan penelitian, sampel, instrument (alat ukur) dan ringkasan hasil atau temuan. Terdapat 10 literatur yang membahas tentang model pembelajaran renang pada anak usia dini, semua jurnal tersebut adalah jurnal nasional yang dilakukan pencarian diportal google scholar dengan mengetik kata kunci "model pembelajaran renang" yang kemudian dianalisis menggunakan analisis critical appraisal untuk menganalisis dari inti jurnal, hasil studi sehingga mengetahui persamaan dan perbedaan dari jurnal-jurnal tersebut. Dari 10 jurnal tersebut ada 5 jurnal tidak dilakukan pemeriksaan permainan renang secara langsung ada yang membahas motoric kasar, permainan modifikasi dan kemampuan. Beberapa hal penting yang didapat dari beberapa jurnal diantaranya identifikasi metode pembelajaran Olahraga renang anak usia dini dengan menjabarkan metode yang efektif dari beberapa penelitian terkait secara runtut agat dapat dijadikan sebagai sebuah acuan pembelajaran olahraga Olahraga renang anak usia dini. Kedua, model pembelajaran Olahraga renang pada anak usia dini dapat meningkatkan semangat dan mencegah kebosanan pada anak usia dini. Ketiga, memberikan pengaruh yang positif terhadap kemampuan motorik kasar dan kognitif anak usia dini serta proses pembelajaran lebih menyenangkan dan partisipatif.
\end{abstract}

Kata Kunci: Penelitan Kepustakaan, Model Pembelajaran Renang, Anak Usia Dini

Submitted Apr 3, 2021 | Revised Apr 25, 2021 | Accepted Apr 27, 2021 


\section{Pendahuluan}

Pendidikan menjadi salah satu proses penting dalam kehidupan setiap individu dan memiliki fungsi serta peran penting bagi pembentukan karakter bangsa suatu negara. Pendidikan jasmani adalah salah bagian dari pendidikan tersebut, maka dari itu proses pendidikan jasmani sangat diperlukan bagi para siswa sebagai generasi penerus bangsa (Mikarsa, , 2007). Pendidikan yang utama dan yang pertama harus diberikan sejak dini adalah pendidikan jasmani dan kesehatan.

Pendidikan jasmani dan kesehatan (Penjaskes) adalah bagian terintegrasi dari pendidikan secaara keseluruhan bertujuan untuuk mengembangkan kebugaran jasmani, berpikir kritis, keterampilan gerak, stabilitas emosional, keterampilan sosial, tindakan moral, dan pengenalan lingkungan bersih aspek pola hidup sehat (Erfayliana, 2015; Herdiyana \& Prakoso, 2016; Sulastri, 2019). Pendidikan dilakukan lewat sebuah kegiatan jasmani dan olahraga kesehatan yang dipilih dan telah di rencanakan dengan sistematis untuk mencapai tujuan pendidikan nasional. Tujuan pendidikan jasmani adalah untuk merangsang perkembangan dan pertumubuhan organik, keterampilan neuromuskuler motorik, perkembangan intelektual, dan Perkembangan emosional (Ateng, 2003).

Pakar penjaskes dari Amerika, Siedentop (1991), menjelaskan bahwa penjas diterima dengan luas sebagai sebuah model pendidikan lewat aktivitas jasmani yang berkembang dari merebaknya telaah pendidikangerak pada perkiraan akhir abad ke-20 ini dan memberi penekanan pada kebugaran jasmani, penguasaan keterampilan, pengetahuan, dan perkembangan sosial.

Proses pembelajaran pendidikan jasmani baik guru maupun pelatih juga harus mempertimbangkan keseluruhan aspek kepribadian anak sehingga pengukuran proses serta produk memiliki kedudukan yang sama pentingnya (Pane \& Saragih, 2018). Kegiatan sebagai proses jasmani dimaksudkan sebagai kegiatan anak didik dalam meningkatkan keterampilan motoriik dan nilai fungsional meliputi aspek kognitif, afektif dan sosial. Sehingga dengan kegiatan penjas diharapkan peserta didik dapat menumbuhkembangkan jasmani maupun perkembangan pribadi anak secara harmonis.

Aktivitas pendidikan fisik merupakan pendidikan jasmani yang tujuannya menlingkupi segala aspek perkembangan kependidiikan, termasuk pertumbuhan sosial dan mental anak. Melalui pendidikan jasmani aspek psikomotor, afektif dan kognitif siswa dapat berkembang dengan baik. Aspek kognitif mencakup perkembangan intelektual, aspek afektif mencakup perkembangan personal, sosial dan emosional serta aspek psikomotorik yang mencakup tentang syaraf otot mulai dari kegiatan reflek yang tanpa disengaja sampai penampilan aspek keterampilan olahraga. Aktivitas jasmani yang diberikan dalam pendidikan jasmani adalah berupa aktivitas bermain dan olahraga. Pendidikan jasmani berpusa pada segala bentuk kegiatan aktivitas jasmani dalam mengaktifkan otot besar (gross motorik). Juga memusatkan pada gerakan fisik dalam permainan, olahraga.

Majunya pendidikan suatu bangsa salah satunya faktornya merupakan tanggungjawab seorang pendidik. Pendidik bertugas sebagai pengajar dan mendidik anak dalam hal ini siswa agar mampu berrprestasi. Oleh karena itu, pendidik harus memiliki kemampuan mumpuni dengan memberikan pendekatan yang terbaik kepada anak. Pendidik dalam hal ini guru hendaknya menggunakan pendekatan yang diharapkan mampu memberikan hal baik kepada siswa baik psikis maupun fisik. Dengan demikian, apabila metode yang dipilih cocok atau tepat maka akan tercipta proses pembelajran yang produktif dan efektif untuk anak.

Selain metode pembelajaran yang tepat, faktor lain yang mempengaruhi keberhasilan dalam proses pembelajaran keterampilan teknik dasar renang adalah kelompok umur. Penampilan seorang anak juga dipengaruhi oleh faktor umur. Faktor umur memiliki tingkat perkembangan yang berbeda secara kapasitas. Setiap kelompok umur memiliki perbedaan kapasitas fisik, mental dan sosial yang disebabkan oleh faktor lingkungan. Perbedaan ini berimplikasi terhadap proses pembelajaran. Anak yang memiliki tahapan umur lebih tinggi memiliki aspek kognisi yang lebih tinggi pula.

Pada aspek kognisi mempengaruhi penerimaan informasi; makin tinggi tingkat kognisi makin mudah menerima informasi. Aktifitas fisik anak disesuaikan dengan pertumbuhan fisik dan 
perkembangan emosionalnya. Bentuk-aktifitas fisikal disesuaikan berdasarkan jenjang umurnya: pada periode usia 7-8 tahun (SD kelas 1 dan 2), pada periode usia 9 tahun (SD kelas 3), pada periode usia 1011 tahun (kelas 4 dan 5), dan pada periode usia 12-13 tahun (kelas 6).

Fakta dilapangan menunjukkan bahwa pembelajaran khususnya olahraga kurang memperhatikan karakteristik siswa yang didasarkan pada perkembangan usia. Cara memberikan pembelajaran olahraga di sekolah dasar disamaratakan, siswa kelas III diberikan pembelajaran yang sama dengan siswa kelas VI. Karakteristik mental, fisik dan sosial dipastikan memiliki perbedaan, oleh karena itu semestinya diberikan model pendekatan pembelajaran yang berbeda. Usia anak Sekolah Dasar diperkirakan antara 7 - 12 tahun, berdasarkan hal tersebut maka peneliti akan mengambil sampel siswa pada kelompok umur 8-11 tahun yang diperkirakan duduk dikelas III - VI. Uraian diatas menimbulkan permasalahan apakah ada perbedaan hasil pembelajaran yang diberikan kepada anak yang memiliki perbedaan usia. Padahal dalam teori, renang dapat diprkenalkan pada anak sejak usia dini berkisar pada umur 3-7 tahun, umur spesialisasi pada usia 10-12 tahun (Bompa, 1994).

Kurikulum pendidikan sekolah dasar dalam hal ini pada periode usia dini mencantumkan salahsatu cabang olahraga aquatik yaitu cabang olahraga renang. Renang adalah cabang olahraga yang populer di kalangan siswa khususnya dan masyarakat pada umumnya. Olahraga renang di Indonesia sendiri telah dikenal akrab oleh masyarakat bahkan sudah tidak memandang jenis kelamin maupun usia. Tak heran, bahwa semakin banyak pula pengusaha maupun masyarakat luas yang menyediakan sarana prasarana kolam renang. Hal tersebut akan semakin memudahkan dalam pengenalan olahraga renang serta pembibitan atlit dan pembinaan prestasi mulai sejak dini. Olahraga renang juga dikenal sebagai salah satu olahraga air yang menyenangkan serta menarik minat masyarakat

Renang adalah salah satu media bergaul dan bersantai. Olahraga renang adalah aktivitas air dengan banyak macam gaya yang sudah dikenalkan sejak lama dan banyak memberi manfaat kepada manusia. Beberapa langkah yang perlu dilakukan untuk mencapai hal tersebut antara lain memperhatikan peningkatan pengadaan sarana dan prasarana. Sarana dan prasarana olahraga sangatlah penting dalam proses kegiatan pembelajaran ataupun peningkatan presetasi altet/mahasiswa karena sarana dan prasarana menjadi pilar utama dalam mendukung setiap kegiatan yang berhubungan dengan aktivitas olahraga (Irawan, 2017).

Menurut (Arhesa, et.al , 2020), faktor-faktor penghambat belajar renang terdiri dari sarana dan prasarana sebanyak $62.5 \%$, resiko belajar renang sebanyak $69.6 \%$, rasa cemas pada saat belajar renang sebanyak $64.7 \%$, rasa takut pada saat belajar renang sebanyak $73 \%$, dan pengaruh lingkungan sebanyak $45 \%$. Sehingga dari hasil tersebut diketahui bahwa faktor resiko, cemas, dan takut lebih menghambat dibandingkan dengan faktor belajar renang lainnya seperti sarana dan prasarana serta lingkungan

Selain sarana dan prasarana olahraga juga harus memperhatikan panduan bakat, peningkatan kualitas pembinaan dan pelatihan. Sehingga dalam mengupayakan itu semua perlu dimulai dengan melakukan pembinaan secara berkelanjutan yang dimulai sejak usia dini. Dalam menentukan perenang yang berbakat yang masih relatif muda hanya dapat ditemukan di sekolah-sekolah. Pemahaman akan kemampuan teknik dasar sangatlah penting dalam olahraga renang. Hal itu sangat penting untuk menunjang dalam keberhasilan berenang.

Pemahaman teknik dasar sangat diutamakan untuk mencapai prestasi yang maksimal. Agar siswa dapat berenang dengan benar, mereka di tuntut untuk mampu melakukan unsur gerak dari teknik dasar olahraga renang sehingga penguasaaan teknik dasar harus dikedepankan dalam proses pembelajaran. Agar teknik dapat maksimal perlu dilatih secara sistematis dan berkesinambungan. Menurut, (Schmidt, 1991), untuk menguasai suatuketerampilan gerak perlu di lakukan dalam latihan secara berkesinambungan sebagai sebuah proses dari fase Short-Term Memory (STM) ke fase Long-Term Memory (LTM) sehingga menjadi keterampilan yang menetap, seperti pada waktu belajar mengendarai sepeda dan belajar berenang. 
Pemberian metode yang tepat dalam olahraga renang untuk anak usia dini tentu harus mendapat perhatian. Akan tetapi masih ditemukan berbagai macam kendala di lapangan dalam metodenya. Kenyataannya di lapangan menunjukkan bahwa guru pendidikan jasmani telah mengalami kesulitan atau kendala dalam mengajarkan pokok bahasan renang. Mereka hanya memberikan pelajaran renang hanya dengan teori saja, sehingga praktik para siswa sekolah dasar umumnya tidak memiliki keterampilan renang secara praktik. Olehhnya itu, perlu ada kajian menyeluruh berupa informasi terkait identifikasi metode pembelajaran yang efektif dalam olahraga renang khususnya untuk anak usia dini. Berdasarkan latar belakang di atas, penelitian bertujuan melakukan kajian literature sebagai sebuah studi kepustakaan sebagai identifikasi metode pembelajaran olahraga renang anak usia dini dengan menjabarkan metode yang efektif dari beberapa penelitian terkait secara runtut agat dapat dijadikan sebagai sebuah acuan pembelajaran olahraga renang anak usia dini di kemudian hari.

\section{Metode Penelitian}

Penelitian ini merupakan penelitan kepustakaan (library research), yakni serangkaian penelitian yang berkaitan dengan metode pengumpulan data pustaka, atau penelitian yang objek penelitiannya ditelusuri dan digali melalui berbagai informasi kepustakaan melalui (buku, ensiklopedi, jurnal ilmiah, koran, majalah, dan dokumen (Syaodih N, 2009). Kajian literature atau penelitian kepustaan (literature review) adalah penelitian yang meninjau dan mengkaji secara kritis gagasan, atau temuan yang terdapat di dalam literature yang berorientasi akademik serta merumuskan kontribusi teoritis dan metodologisnya untuk topik tertentu (Imam M, 2010).

Data yang digunakan dalam penelitian ini adalah data sekunder. Data sekunder adalah data yang diperoleh bukan dari pengamatan langsung. melainkan data tersebut didapat dari hasil penelitian yang telah dilakukan oleh peneliti terdahulu. Sumber data sekunder yang dimaksudkan berupa laporan ilmiah primer yang terdapat di dalam artikel atau jurnal berkaitan dengan metode pembelajaran olahraga renang untuk anak usia dini, serta buku-buku terkait.

Metode pengumpulan data yang digunakan dalam penelitian ini adalah metode dokumentasi. Metode dokumentasi adalah metode pengumpulan data dengan menggali dan mencari data dari literatur yang terkait dengan apa yang ada dalam rumusan masalah (Arikunto, 2010). Data yang telah di dapatkan dari berbaagai literature kemudian dikumpulkan sebagai kesatuan dokumen yang digunakan dalam menjawab permasalahan yang telah dirumuskan.

Strategi penelusuran artikel publikasi dengan menggunakan kata kunci di google scholar, EBSCO, dan Proquest maupun akses pencarian jurnal berputasi lainnya menggunakan kata kunci yang dipilih yakni: Model Pembelajaran, Renang dan anak usia dini. Artikel atau jurnal yang sesuai dengan kriteria di diambil untuk selanjutnya dianalisis. Literature Review ini menggunakan literatur yang dapat diakses fulltext dalam format pdf dan scholarly (peer reviewed journals).

Kriteria jurnal yang direview adalah artikel jurnal penelitian berbahasa Indonesia dan Inggris dengan subjek renang anak usia dini, jenis jurnal artikel penelitian bukan literature review dengan tema renang anak usia dini. Jurnal yang sesuai dengan kriteria kemudian dilakukan review.

Artikel penelitian yang sesuai dengan kriteria kemudian dikumpulkan dan dibuat ringkasan jurnal meliputi nama peneliti, tahun terbit jurnal, rancangan studi, tujuan penelitian, sampel, instrument (alat ukur) dan ringkasan hasil atau temuan. Ringkasan jurnal penelitian tersebut dimasukan ke dalam tabel diurutkan sesuai alfabel dan tahun terbit jurnal dan sesuai dengan format tersebut di atas. Untuk lebih memperjelas analisis abstrak dan full text jurnal dibaca dan dicermati. Ringkasan jurnal tersebut kemudian dilakukan analisis terhadap isi yang terdapat dalam tujuan penelitian dan hasil/temuan penelitian. Metode analisis yang digunakan menggunakan analisis isi jurnal. 


\section{Hasil dan Pembahasan}

Literature review ini dilakukan untuk mengetahui model pembelajaran olahraga renang pada anak usia dini dengan teknik pengumpulan literatur yang sudah ada mengenai model pembelajaran olahraga renang. Literatur yang terkumpul dianalisis dengan tabel Critical Appraisal untuk menjawab tujuan dari pengukuran dan dibandingkan dengan hasil pengukuran sederhana. Terdapat 10 literatur yang membahas tentang model pembelajaran Olahraga renang pada anak usia dini semua jurnal tersebut adalah jurnal nasional yang dilakukan pencarian diportal google scholar dengan mengetik kata kunci "model pembelajaran renang" yang kemudian dianalisis menggunakan analisis critical appraisal untuk menganalisis dari inti jurnal, hasil studi sehingga mengetahui persamaan dan perbedaan dari jurnaljurnal tersebut. Berikut ini adalah tabel analisis critical appraisal dari 10 jurnal:

Tabel 1. Review 10 Jurnal

\begin{tabular}{|c|c|c|c|c|}
\hline No & $\begin{array}{l}\text { Penulis Jurnal (Tahun) dan } \\
\text { Judul }\end{array}$ & Inti Jurnal & Hasil Studi & $\begin{array}{l}\text { Persamaan dan perbedaan } \\
\text { dengan peneliti skripsi }\end{array}$ \\
\hline 1 & $\begin{array}{l}\text { Lutfi nur, anne hafnia, } \\
\text { nandang rusmana, } 2020 . \\
\text { "kemampuan kognitif anak } \\
\text { usia dini dalam } \\
\text { pembelajaran akuatik". }\end{array}$ & $\begin{array}{l}\text { Membahas } \\
\text { mengenai } \\
\text { kemampuan } \\
\text { kognitif anak usia } \\
\text { dini pada } \\
\text { pembelajaran } \\
\text { akuatik. }\end{array}$ & $\begin{array}{l}\text { Hasil studi berfokus } \\
\text { pada kemampuan } \\
\text { kognitif anak usia } \\
\text { dini belum } \\
\text { berkembang dengan } \\
\text { optimal, sehingga } \\
\text { perlu upaya untuk } \\
\text { mengatasi. }\end{array}$ & $\begin{array}{l}\text { Persamaan: sama-sama } \\
\text { membahas akuatik/renang } \\
\text { pada anak usia dini. } \\
\text { Perbedaan: tidak } \\
\text { membahas model } \\
\text { pembelajaran renang pada } \\
\text { anak usia dini. }\end{array}$ \\
\hline 2 & $\begin{array}{l}\text { Ermawan susanto, } 2012 . \\
\text { "model pembelajaran } \\
\text { akuatik siswa prasekolah". }\end{array}$ & $\begin{array}{l}\text { Membahas } \\
\text { mengenai model } \\
\text { pembelajaran } \\
\text { akuatik siswa } \\
\text { prasekolah }\end{array}$ & $\begin{array}{l}\text { Hasil studi berfokus } \\
\text { pada produk model } \\
\text { pembelajaran akuatik } \\
\text { prasekolah } \\
\text { memberikan } \\
\text { pengaruh yang baik } \\
\text { terhadap aspek fisik, } \\
\text { psikomotor, kognitif } \\
\text { dan afektif }\end{array}$ & $\begin{array}{l}\text { Persamaan: } r \text { sama-sama } \\
\text { membahas } \\
\text { pembelajaran akuatik pada } \\
\text { anak usia dini. } \\
\begin{array}{l}\text { Perbedaan: tidak ada uji } \\
\text { sampel }\end{array}\end{array}$ \\
\hline 3 & $\begin{array}{l}\text { Sartono, firman adityatama, } \\
\text { 2018. "pengaruh metode } \\
\text { pembelajaran renang } \\
\text { terhadap kondisi fisik pada } \\
\text { anak usia } 8 \text { tahun }\end{array}$ & $\begin{array}{l}\text { Membahas } \\
\text { mengenai metode } \\
\text { pembelajaran } \\
\text { renang terhadap } \\
\text { kondisi fisik. }\end{array}$ & $\begin{array}{l}\text { Hasil studi berfokus } \\
\text { pengaruh yang } \\
\text { signifikan antara } \\
\text { metode } \\
\text { pembelajaran renang } \\
\text { terhadap kondisi } \\
\text { fisik pada anak usia } \\
8 \text { tahun }\end{array}$ & $\begin{array}{l}\text { Persamaan; sama } \\
\text { membahas } \\
\text { pembelajaran renang. } \\
\text { Perbedaan: tidak } \\
\text { menggambarkan } \\
\text { model pembelajaran } \\
\text { renang pada anak usia } \\
\text { dini. }\end{array}$ \\
\hline 4 & $\begin{array}{l}\text { Tri Alim Saputra Hidayat, } \\
2019 . \\
\text { "model } \\
\text { pembelajaran keterampilan } \\
\text { renang gaya bebas (TriAs) } \\
\text { untuk anak usia sekolah } \\
\text { dasar. }\end{array}$ & $\begin{array}{l}\text { Membahas model } \\
\text { pembelajaran } \\
\text { keterampilan } \\
\text { renang gaya bebas } \\
\text { untuk anak usia } \\
\text { sekolah dasar }\end{array}$ & $\begin{array}{l}\text { Hasil studi } \\
\text { berfokus pada } \\
\text { penerapan dan } \\
\text { pengembangan } \\
\text { model } \\
\text { pembelajaran } \\
\text { dan efektifitas, } \\
\text { efesiensi model. }\end{array}$ & $\begin{array}{l}\text { Persamaan: sama- } \\
\text { sama membahas } \\
\text { model pembelajaran } \\
\text { Perbedaan: tidak } \\
\text { membahas permainan } \\
\text { Olahraga renang pada } \\
\text { anak usia dini. }\end{array}$ \\
\hline 5 & $\begin{array}{l}\text { Hernawan, widiastuti, } \\
\text { apprillia intan timur, } \\
\text { karisdha pradityana, } \\
2018 . \quad \text { "pengembangan } \\
\text { model pengenalan air } \\
\text { untuk anak usia dini". }\end{array}$ & $\begin{array}{l}\text { Membahas } \\
\text { pengenalan air } \\
\text { untuk anak usia } \\
\text { dini. }\end{array}$ & $\begin{array}{l}\text { Hasil studi model } \\
\text { pengenalan air } \\
\text { untuk anak usia } \\
\text { dini meningkatkan } \\
\text { kemampuan awal } \\
\text { anak dalam } \\
\text { berenang. }\end{array}$ & $\begin{array}{l}\text { Persamaan: } \\
\text { membahas } \\
\text { pembelajaran } \text { metode } \\
\text { renang pada anak usia } \\
\text { dini } \\
\text { Perbedaan: tidak ada } \\
\text { penilaian langsung. }\end{array}$ \\
\hline 6 & $\begin{array}{lr}\text { Lutfi nur, anne hafina, } \\
\text { nandang } & \text { rusmana, } \\
\text { rafdlal, } & 2019 . \\
\text { "Kemampuan } & \text { motorik } \\
\end{array}$ & $\begin{array}{l}\text { Membahas } \\
\text { kemampuan } \\
\text { motorik dasar } \\
\text { anak usia dini }\end{array}$ & $\begin{array}{l}\text { Hasil studi } \\
\text { menunjukkan } \\
\text { kemampuan } \\
\text { motorik dasar }\end{array}$ & $\begin{array}{l}\text { Persamaan: sama-sama } \\
\text { membahas } \\
\text { pembelajaran akuatik } \\
\text { pada anak usia dini }\end{array}$ \\
\hline
\end{tabular}




\begin{tabular}{|c|c|c|c|c|}
\hline & $\begin{array}{l}\text { dasar anak usia dini } \\
\text { dalam pembelajaran } \\
\text { akuatik". }\end{array}$ & $\begin{array}{l}\text { dalam } \\
\text { pembelajaran } \\
\text { akuatik }\end{array}$ & $\begin{array}{l}\text { anak usia dini } \\
\text { dalam } \\
\text { pembelajaran } \\
\text { akuatik berada } \\
\text { pada kategori } \\
\text { mulai berkembang }\end{array}$ & $\begin{array}{l}\text { Perbedaan: membahas } \\
\text { kemampuan motoric } \\
\text { dasarnya saja. }\end{array}$ \\
\hline 7 & $\begin{array}{l}\text { Yusrifar mujibuddin, } \\
\text { oman unju subandi, andri } \\
\text { irawan, 2018, "model } \\
\text { pembelajaran pernapasan } \\
\text { renang melalui } \\
\text { permainan di air untuk } \\
\text { siswa prasekolah dan } \\
\text { taman kanak-kanak". }\end{array}$ & $\begin{array}{l}\text { Membahas } \\
\text { model } \\
\text { pembelajaran } \\
\text { pernapasan } \\
\text { renang melalui } \\
\text { permainan di air. }\end{array}$ & $\begin{array}{l}\text { Hasil studi } \\
\text { berfokus model } \\
\text { pembelajaran } \\
\text { pernapasan } \\
\text { renang melalui } \\
\text { permainan di air. } \\
\text { dapat digunakan } \\
\text { dalam proses } \\
\text { kegiatan belajar } \\
\text { mengajar. }\end{array}$ & $\begin{array}{l}\text { Persamaan: sama-sama } \\
\text { membahas model } \\
\text { pembelajaran renang. } \\
\text { Perbedaan; tidak ada } \\
\text { membahas permainan } \\
\text { Olahraga renang pada } \\
\text { anak usia dini }\end{array}$ \\
\hline 8 & $\begin{array}{l}\text { Hariadi, suryansah, M. } \\
\text { sururuddin, yul alfian } \\
\text { hadi, suhirman, } 2020 . \\
\text { "model Latihan motoric } \\
\text { halus melalui akuatik } \\
\text { introduction } \\
\text { cooperative game anak } \\
\text { usia dini". }\end{array}$ & $\begin{array}{l}\text { Membahas } \\
\text { model Latihan } \\
\text { motorik halus } \\
\text { pada anak usia } \\
\text { dini. }\end{array}$ & $\begin{array}{l}\text { Hasil studi } \\
\text { menunjukkan } \\
\text { bahwa ada } \\
\text { hubungan Latihan } \\
\text { motoric halus } \\
\text { melalui akuatik } \\
\text { introduction to } \\
\text { cooperative dan } \\
\text { game anak usia } \\
\text { dini. }\end{array}$ & $\begin{array}{l}\text { Persamaan: sama-sama } \\
\text { membahas akuatik pada } \\
\text { anak usia dini. } \\
\text { Perbedaan; membahas } \\
\text { model Latihan motoric } \\
\text { pada anak usia dini }\end{array}$ \\
\hline 9 & $\begin{array}{l}\text { Anik lestariningrum, } \\
\text { 2019. "pengaruh senam } \\
\text { bebek berenang terhadap } \\
\text { kemampuan motori kasar } \\
\text { anak usia 3-4tahun }\end{array}$ & $\begin{array}{l}\text { Membahas } \\
\text { pengaruh senam } \\
\text { bebek dari } \\
\text { kegiatan senam } \\
\text { bebek }\end{array}$ & $\begin{array}{l}\text { Hasil studi } \\
\text { terdapat pengaruh } \\
\text { signifikan dari } \\
\text { kegiatan senam } \\
\text { bebek berenang } \\
\text { pada anak usia } \\
\text { dini. }\end{array}$ & $\begin{array}{l}\text { Persamaan; sama-sama } \\
\text { membahas permainan } \\
\text { Olahraga renang. } \\
\text { Perbedaan; tidak ada } \\
\text { membahas model } \\
\text { pembelajaran Olahraga } \\
\text { renang pada anak usia } \\
\text { dini. }\end{array}$ \\
\hline 10 & $\begin{array}{l}\text { Rico mahendra dinata, } \\
\text { siti nurrochmah, tatok } \\
\text { sugiarto, } \\
\text { "pengembangan variasi } \\
\text { model Latihan renang } \\
\text { gaya bebas untuk pemula } \\
\text { diperkumpulan renang } \\
\text { taman harapan malang }\end{array}$ & $\begin{array}{l}\text { Membahas } \\
\text { pengembangan } \\
\text { variasi model } \\
\text { Latihan renang } \\
\text { gaya bebas } \\
\text { untuk pemula }\end{array}$ & $\begin{array}{l}\text { Hasil studi } \\
\text { pengembangan } \\
\text { variasi model } \\
\text { Latihan Teknik } \\
\text { renang gaya bebas } \\
\text { layak digunakan. }\end{array}$ & $\begin{array}{l}\text { Persamaan; sama-sama } \\
\text { membahas permainan } \\
\text { Olahraga renang. } \\
\text { Perbedaan; tidak ada } \\
\text { membahas model } \\
\text { pembelajaran Olahraga } \\
\text { renang pada anak usia } \\
\text { dini. }\end{array}$ \\
\hline
\end{tabular}

Berdasarkan critical appraisal, dari 10 jurnal terdapat 5 jurnal yang membahas mengenai permainan Olahraga renang pada anak usia dini. Penjelasan tersebut diinterprestasikan dalam table berikut:

Tabel 2. 5 Jurnal yang Berkaitan dengan Permainan Olahraga Renang pada Anak Usia Dini

\begin{tabular}{llcll}
\hline No & \multicolumn{1}{c}{ Penulis Jurnal } & $\begin{array}{c}\text { Tahun } \\
\text { Publikasi }\end{array}$ & \multicolumn{2}{c}{$\begin{array}{c}\text { Pemeriksaan Permainan } \\
\text { Renang }\end{array}$} \\
\hline 1 & $\begin{array}{l}\text { Lutfi nur, anne hafnia, nandang } \\
\text { rusmana }\end{array}$ & 2020 & $\begin{array}{l}\text { Tidak dilakukan } \\
\text { secara langsung }\end{array}$ & pemeriksaan \\
\hline 2 & $\begin{array}{l}\text { Hariadi, suryansah, } \\
\text { sururuddin, yul alfian hadi, } \\
\text { suhirman }\end{array}$ & 2020 & $\begin{array}{l}\text { Tidak dilakukan } \\
\text { secara langsung }\end{array}$ & pemeriksaan \\
\hline 3 & $\begin{array}{l}\text { Lutfi nur, anne hafina, nandang } \\
\text { rusmana, rafdlal }\end{array}$ & 2019 & $\begin{array}{l}\text { Tidak dilakukan pemeriksaan } \\
\text { secara langsung }\end{array}$ & peran \\
\hline 4 & $\begin{array}{l}\text { Hernawan, widiastuti, apprillia } \\
\text { intan timur, karisdha pradityana. }\end{array}$ & 2018 & $\begin{array}{l}\text { Tidak dilakukan } \\
\text { secara langsung }\end{array}$ & pemeriksaan \\
\hline 5 & $\begin{array}{l}\text { Yusrifar mujibuddin, oman unju } \\
\text { subandi, andri irawan }\end{array}$ & 2018 & $\begin{array}{l}\text { Tidak dilakukan } \\
\text { secara langsung }\end{array}$ & pemeriksaan \\
\hline
\end{tabular}


Lutfi Nur, Anne Hafina, Nandang Rusmana (2020) dalam artikelnya yang berjudul "Kemampuan Kognitif Anak Usia Dini Dalam Pembelajaran Akuatik". Menjelaskan bahwa Hasil penelitian menunjukkan bahwa kemampuan kognitif anak usia 5-6 tahun di TK Laboratorium Percontohan UPI Kampus Tasikmalaya secara keseluruhan pada persentase 20\% (2 anak) yang masuk kedalam kategori berkembang sangat baik,20\% (2 anak) yang masuk pada kategoriberkembang sesuai harapan, dan 20\% (2 anak) pada kategori mulai berkembang. Sedangkan 40\% (4 anak) sisanya pada kategori belum berkembang. Berdasarkan hasil penelitian tersebut menandakan bahwa kemampuan kognitif anak usia dini belum berkembang dengan optimal, sehingga perlu adanya berbagai upaya untuk mengatasi hal tersebut.

Hariadi, suryansah, M. sururuddin, yul alfian hadi, suhirman (2020) dalam artikelnya yan berjudul "Model Latihan Motorik Halus Melalui Aquatic Introduction to Cooperative Game Anak Usia Dini". Menjelaskan bahwa ada hubungan Latihan Motorik Halus Melalui Akuatik Introduction to Cooperative dan Game Anak Usia Dini. Hasil pada saat lemparan pertama kelompok A hanya mampu memmasukkan bola plastic ke dalam keranjang sebanyak $5 \%$ dan kelompok B sebanyak 4. 5\%. Kemudian pada lemparan ke dua kelompok A sebanyak $7 \%$ dan Kelompok B sebanyak $10 \%$. Pada kesempatan kedua kelompok A disuruh untuk mengangkat dan menyebut huruf yang dipegang, semua peserta mengenal huruf dan bisa menyebut huruf yang dipegang hal yang sama juga dilakukan pada kelompok B. Namun pada kelompok B hanya satu peserta yang belum bisa menyebut huruf namun sudah mengenal huruf yang ditunjukkan. Kalau dipersentasekan dari kesempatan pertama kelompok A yang sudah mengenal huruf sebanyak 20\% dan kelompok B sebanyak 10\% sedangkan yang belum bisa mengenal huruf dari kelompok A sebanyak 30\% dan kelompok B sebanyak 40\%. Setelah diberikan kesempatan kedua kelompok A yang sudah bisa menyebut dan mengenal angka sebanyak 100\% dan pada kelompok B Sebanyak $90 \%$.

Lutfi nur, anne hafina, nandang rusmana, rafdlal (2019) dalam artikelnya yan berjudul "Kemampuan Motorik Dasar Anak Usia Dini Dalam Pembelajaran Akuatik". Hasil penelitian menunjukkan kemampuan motorik dasar anak usia dini dalam pembelajaran akuatik berada pada kategori mulai berkembang. Penelitian ini menggunakan metode deskriptif. Subyek dalam penelitian ini adalah siswa taman kanak-kanak di kelas B yang berusia 5-6 tahun sebanyak delapan orang (laki-laki 5 dan perempuan 3). Instrumen dalam penelitian ini menggunakan observasi terstruktur, catatan lapangan, dan dokumentasi mengenai motorik dasar anak yang meliputi pengenalan air, masuk ke kolam renang, kontrol napas, posisi tubuh, mengapung, dorongan lengan, istirahat lengan, gerakan tungkai dan gerakan kombinasi.

Hernawan, widiastuti, apprillia intan timur, karisdha pradityana (2018) dalam artikelnya yang berjudul "Pengembangan Model Pengenalan Air Untuk Anak Usia Dini". Hasil penelitian dan pengembangan model pengenalan air untuk anak usia dini menunjukkan bahwa (1) model peneganalan air untuk anak usia dini signifikan meningkatkan kemampuan awal anak dalam berenang, (2) hasil uji validasi oleh ahli renang menunjukan bahwa 25 item model layak untuk diterapkan dalam proses pengenalan air untuk anak usia dini, (3) keefektifan model pengenalan airditunjukkan dengan hasil pretest dan post-test anak diperoleh hasil t-hitung 21.67 lebih besar dari t-tabel, serta Sig(2-tailed) $<0.05$ $(\alpha)$. Artinya terdapat peningkatan antara sebelum dan sesudah adanya treatment.

Yusrifar mujibuddin, oman unju subandi, andri irawan (2018) dalam artikel nya yang berjudul "Model Pembelajaran Pernapasan Renangmelalui Permainan Di Air Untuk Siswa Prasekolah Dan Taman Kanak-Kanak". Hasil penelitian ini menyimpulkan bahwa model pembelajaran pernafasan menggunakan alat dan tanpa alat melalui permainan di air dapat digunakan dalam proses kegiatan belajar mengajar, sehingga dapat memberikan kontribusi untuk menigkatkan teknik dan ketrampilan bernapas. 


\section{Kesimpulan}

Melihat dari penelitian diatas tentang model pembelajaran Olahraga renang pada anak usia dini (literatur review) yang telah dijabarkan dalam beberapa hal penting maka dapat disimpulkan bahwa: pertama sebagai identifikasi metode pembelajaran Olahraga renang anak usia dini dengan menjabarkan metode yang efektif dari beberapa penelitian terkait secara runtut agat dapat dijadikan sebagai sebuah acuan pembelajaran olahraga Olahraga renang anak usia dini. Kedua, model pembelajaran Olahraga renang pada anak usia dini dapat meningkatkan semangat dan mencegah kebosanan pada anak usia dini. Ketiga, memberikan pengaruh yang positif terhadap kemampuan motorik kasar dan kognitif anak usia dini serta proses pembelajaran lebih menyenangkan dan partisipatif.

\section{Daftar Pustaka}

Ateng, A. 2003. Olahraga di sekolah. Dalam perkembangan Olabraga Terkini, Kajian Para Pakar. Jakarta: PT. Raja Garfindo Persada.

Arhesa, S., Sofyan, D., \& Ramadhan, M. F. (2020). Identifikasi Faktor-Faktor Penghambat Belajar Renang. Jurnal Respecs, 2(2).

Arikunto, S. (2010). Metode Peneltian. Jakarta: Rineka Cipta.

Bandara, W., Miskon, S., \& Fielt, E. (2011). A systematic, tool-supported method for conducting literature reviews in information systems. In 19th European Conference on Information Systems, ECIS 2011. Helsinki, Finland.

Bompa, T. O. (1994). Theory and methodology of training: the key to athletic performance. Kendall hunt publishing company.

Burhaein, E. (2017). Aktivitas fisik olahraga untuk pertumbuhan dan perkembangan siswa SD. Indonesian Journal of Primary Education, 1(1), 51-58.

Cholik dan Lutan. 1998. Strategi Pembelajaran pendidikan Jasmani dan Kesehatan. Jakarta : Direktur Jendral Pendidikan Dasar dan Menengah.

Darmawan, A., \& Destiasari, C. (2019). Pengembangan Model Latihan Renang Gaya Dolphin Untuk Pemula. In Prosiding Seminar Nasional IPTEK Olahraga (SENALOG) (Vol. 2, No. 1).

Denney, A. S., \& Tewksbury, R. (2013). How to write a literature review. Journal of criminal justice education, 24(2), 218-234.

Erfayliana, Y. (2015). Pendidikan Jasmani Dalam Membentuk Etika, Moral, dan Karakter. TERAMPIL: Jurnal Pendidikan dan Pembelajaran Dasar, 2(2), 302-315.

Mikarsa, H. L. (2007). Pendidikan Anak di SD. Jakarta: Universitas Terbuka

Herdiyana, A., \& Prakoso, G. P. W. (2016). Pembelajaran Pendidikan Jasmani Yang Mengacu Pada Pembiasaan Sikap Fair Play Dan Kepercayaan Pada Peserta Didik. Jorpres (Jurnal Olabraga Prestasi), 12(1).

Hernawan, H., Widiastuti, W., Timur, A. I., \& Pradityana, K. (2018). Pengembangan Model Pengenalan Air untuk Anak Usia Dini. Jurnal Pendidikan Usia Dini, 12(2), 251-260.

Irawan, R. (2017). Studi Kelayakan Fasilitas Sarpras Olahraga Indoor Di FIK UNNES. Jurnal Penjakora, 4(1), 90-102.

Mohammad, I. F. (2010). Pengembangan Asesmen Diri Siswa (Student Self-Assessment) sebagai Model Penilaian dan Pengembangan Karakter. Prosiding Konferensi Ilmiah Nasional "Asesmen dan Pembangunan Karakter Bangsa” HEPI UNES A 2012.

Mujibuddin, Y., Subandi, O. U., \& Irawan, A. (2018). Model Pembelajaran Pernapasan Renang Melalui Permainan di Air untuk Siswa Prasekolah dan Taman Kanak-Kanak. Jurnal Pendidikan Jasmani dan Adaptif, 1(02), 40-45. 
Nan, S. (2009). Metode Penelitian Pendidikan. PT. Remaja Rosdakarya : Bandung. h.52

Novita. L., (2009). Pengaruh Latihan Lari Aerobic dan Renang Terbadap Peningkatan Kebugaran. Skripsi. UNES: Semarang

Pane, B. S., \& Saragih, A. H. (2018). Pengaruh Gaya Mengajar Dan Motor Educability Terhadap Passing Atas Bolavoli Pada Siswa Putra Smp Gajah Mada Medan. Jurnal Teknologi Pendidikan (JTP), 9(1), 1-13.

Ramdhani, M. A. (2017). Lingkungan pendidikan dalam implementasi pendidikan karakter. Jurnal Pendidikan UNIGA, 8(1), 28-37.

Randolph, J. (2009). A guide to writing the dissertation literature review. Practical Assessment, Research, and Evaluation, 14(1), 13.

Schmidt, F., Zimmermann, F., \& Willeke, F. (1991). Comparison of methods to determine long-term stability in proton storage rings. Part. Accel., 35(CERN-SL-91-14-AP), 249-256.

Siedentop, D. (1994). Sport education: Quality PE through positive sport experiences. Human Kinetics Publishers.

Sulastri, S. (2019). Upaya Meningkatkan Kemampuan Siswa dalam Melakukan Passing Bawah dengan Modifikasi Pembelajaran Permainan Bola Voli dengan Menggunakan Bola Gantung untuk Meningkatkan Kemampuan Siswa Kelas IV SDN 2 Ketandan Kecamatan Klaten Utara Tahun Pelajaran 2017/2018. Jurnal Pendidikan Dasar, 7(2).

Suryobroto, A. S. (2004). Diktat mata kuliah Sarana dan Prasarana Pendidikan Jasmani. FIK UNY

Susanto, E. (2010). Olahraga Renang Sebagai Hidrotherapy Dalam Mengatasi Masalah-masalah Kesehatan. Jurnal. Bandung: FIK UPI

Widiastuti, W \& Hamamah, F. (2017). Model Pembelajaran Renang (Fh) Bagi Siswa Prasekolah. Jurnal Pendidikan Usia Dini, 11(2), 358-368. 